See Article page 412.

\section{Commentary: A breath of fresh air for thoracic surgeons in the coronavirus disease 2019 (COVID-19) era}

\author{
Sean C. Wightman, MD, and
}

Elizabeth A. David, MD, MAS

Through the coronavirus disease 2019 (COVID-19) pandemic, governing bodies and societies have provided recommendations to minimize risk to those providing care to patients. ${ }^{1}$ Because video-assisted thoracic surgery and robotic surgery are often performed using insufflation of carbon dioxide, they provide a unique exposure risk for members of the health care team through aerosolization. ${ }^{2}$ In this issue of The Journal, Seco and colleagues ${ }^{3}$ have demonstrated their technique to minimize exposure to aerosolized virus particles.

With the increased prevalence of the novel coronavirus, the authors have creatively developed a solution to minimize the risk of increased susceptibility to the virus during thoracic surgical procedures due to prolonged airway and lung parenchymal exposure. Using the da Vinci Xi robotic system (Intuitive Surgical, Sunnyvale, Calif), flow of carbon dioxide was filtered during insufflation and desufflation of the operative space. These ultra-low particulate filters capture and remove the vast majority of organisms contained within any aerosolized particle. ${ }^{3}$ The authors advocate for cumbersome insufflation and desufflation each instrument change and advocate for removing all specimens at the end of the procedure rather than as they are separated from the patient. Although it is recognized this technique

\footnotetext{
From the Division of Thoracic Surgery, Department of Surgery, Keck School of Medicine, The University of Southern California, Los Angeles, Calif.

Disclosures: The authors reported no conflicts of interest.

The Journal policy requires editors and reviewers to disclose conflicts of interest and to decline handling or reviewing manuscripts for which they may have a conflict of interest. The editors and reviewers of this article have no conflicts of interest.

Received for publication June 8, 2020; revisions received June 8, 2020; accepted for publication June 12, 2020; available ahead of print June 20, 2020.

Address for reprints: Elizabeth A. David, MD, MAS, Keck School of Medicine, The University of Southern California, 1510 San Pablo St, Suite 514, Los Angeles, CA 90033 (E-mail: elizabeth.david@med.usc.edu).

JTCVS Techniques 2020;3:415-6

2666-2507

Copyright (C) 2020 The Authors. Published by Elsevier Inc. on behalf of The American Association for Thoracic Surgery. This is an open access article under the CC BY-NCND license (http://creativecommons.org/licenses/by-nc-nd/4.0/).

https://doi.org/10.1016/j.xjtc.2020.06.014
}

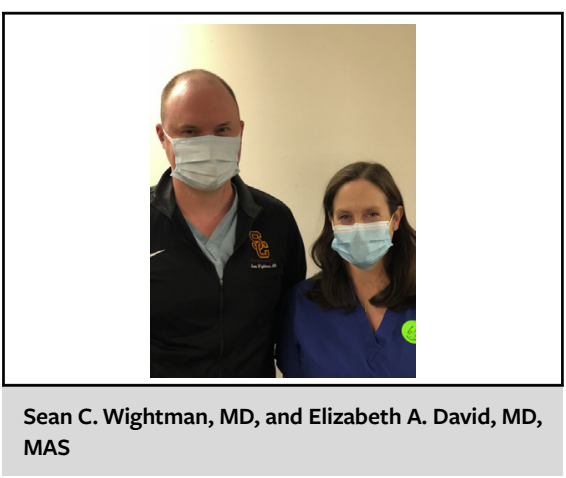

CENTRAL MESSAGE

Dr Seco and colleagues discuss

intraoperative techniques to

potentially reduce viral transmis-

sion during thoracic surgical

procedures.

has not yet been employed on any patients positive for COVID-19, this strategy offers a plausible technique for mitigation of risk.

Risk of infection with COVID-19 increases with exposure time. ${ }^{4}$ Although risk of COVID-19 cannot be eradicated during a thoracic operation, it can be diminished. The method Seco and colleagues advocate for is only safely filtering when the chest is completely contained by ports and instruments. This does not aid during times of port insertion, specimen retrieval, and thoracostomy tube placement, where exposure still exists. With the expansion of the isolated contralateral chest-causing movement of the mediastinum - there is likely a small but present air volume influx and egress on the operative side. Therefore, were a patient to be positive for COVID-19, there is still sufficient time for exposure to those present in the operating room even with insufflation and desufflation filters in place. In addition, port-based chest operations are not always routine for thoracic surgeons, which limits this technique's broad applicability. In the included video, no N95 particulate respirator masks were visibly used, and this addition would likely further decrease viral exposure during thoracic surgery by providing protection during periods of imperfect circuit containment. ${ }^{5}$ Although the technique demonstrates clear potential benefit, the obvious next step in this technique is the inclusion of real-world data demonstrating its efficacy.

In the video, the demonstrated insufflation and desufflation is a rhythmic dance between the scrub nurse and the 
bedside assistant occurring with every instrument change and specimen retrieval. The authors should be commended on devising a technique to minimize viral transmission during robotic operations. This novel technique on minimizing the likelihood of viral aerosolization is truly a breath of fresh air for thoracic surgeons in this era.

\section{References}

1. Thoracic Surgery Outcomes Research Network, Inc. COVID-19 guidance for triage of operations for thoracic malignancies: a consensus statement from thoracic surgery outcomes research network. Ann Thorac Surg. April 4, 2020 [Epub ahead of print].

2. Wolfer RS, Krasna MJ, Hasnain JU, McLaughlin JS. Hemodynamic effects of carbon dioxide insufflation during thoracoscopy. Ann Thorac Surg. 1994;58:404-8.

3. Seco M, Wood J, Wilson MK. COVIDSafe thoracic surgery: minimizing intraoperative exposure to aerosols. J Thorac Cardiovasc Surg Tech. 2020;3: 412-4.

4. Heinzerling A, Stuckey MJ, Scheuer T, Xu K, Perkins KM, Resseger H, et al. Transmission of COVID-19 to health care personnel during exposures to a hospitalized patient-Solano County, California, February 2020. MMWR Morb Mortal Wkly Rep. 2020;69:472-6.

5. Wang X, Pan Z, Cheng Z. Association between 2019-nCoV transmission and N95 respirator use. J Hosp Infect. 2020;105:104-5. 